\title{
AGE DIFFERENCES IN THE INTRAVENOUS GLUCOSE TOLERANCE TESTS AND THE RESPONSE TO INSULIN
}

\author{
BY FELIX A. SILVERSTONE,1 MARTIN BRANDFONBRENER,² NATHAN W. SHOCK, \\ AND MARVIN J. YIENGST
}

\author{
(From the Gerontology Branch, National Heart Institute, National Institutes of Health, \\ Bethesda, and the Baltimore City Hospitals, Baltimore, Md.)
}

(Submitted for publication August 18, 1956; accepted November 7, 1956)

In addition to providing information with regard to the status of carbohydrate metabolism, the time course of the disappearance of injected glucose from the blood stream offers information concerning the overall effectiveness of a variety of physiological mechanisms involved in maintaining homeostasis. In a number of investigations, reduction in glucose tolerance, i.e., a slower rate of return to fasting levels of blood sugar following the oral (1-17) or intravenous (18-20) administration of glucose, has been reported in older people. The diminished glucose tolerance in the older individual might be due to: (a) inadequate release of insulin from the pancreas, or greater inactivation of endogenously released insulin, (b) the loss of functioning protoplasm with increasing age so that less metabolizing tissue is removing glucose from the blood, (c) a diminution in the effectiveness of the metabolic processes involved in the removal of sugar from the blood stream, (d) alterations in the rate of release of glucose from the liver, or (e) a reduction in the volume in which the glucose is originally distributed in the aged. By comparing the glucose and glucose-insulin tolerance tests in the same individual, an estimate of the effect of insulin may be obtained (21-27). In the experiments to be reported, standard amounts of insulin were administered along with glucose to both old and young subjects with the aim of investigating age differences in the response to the insulin.

\section{EXPERIMENTAL METHODS}

Subject selection. Thirty-five male subjects, age 23 to 86 years, were selected on the basis of a detailed history, physical examination and a series of laboratory tests. The presence of any of the following served to exclude

\footnotetext{
1 Present address: Maimonides Hospital, Brooklyn, New York.

2 Present address: Presbyterian Hospital, New York, New York.
}

a subject from the study: (a) history or known evidence of diabetes or glycosuria, (b) severe alcoholism, hepatomegaly, cirrhosis or other liver disease, (c) cardiac decompensation or edema, (d) infections, temperature elevation or acute or chronic trauma (including surgical) within one week of test, or (e) the taking of steroid drugs (other medication such as aspirin was omitted for 12 hours preceding the tests). All were ambulatory in-patients on a routine full hospital diet for at least one week. Fasting blood sugars were within normal limits $(27,28)$ as shown in Table I.

Experimental procedure. The intravenous glucose tolerance test (GTT) and the glucose-insulin tolerance test (GITT) were performed in each subject under basal conditions and separated by an interval of not less than one week. In 8 of the subjects, each of the tests (GTT and GITT) was carried out twice in order to evaluate reliability.

Twenty minutes before either test was begun, a modified Lindeman needle was placed in an antecubital vein and left in place for the duration of the test. The needle was kept patent by heparinization of the stylus and was used subsequently only for withdrawing blood specimens without a tourniquet (29). A vein in the opposite arm was used for the injection of $50 \mathrm{ml}$. of 50 per cent glucose in water over a period of two minutes. For the GITT, 5 units of hyperglycemic factor-free insulin 3 (Lilly), per square meter of body surface area, were rapidly injected, followed immediately by the standard amount of glucose. The fasting blood specimen was obtained through the Lindeman needle a few minutes before zero time, which was recorded as the beginning of the injection of glucose.

Blood samples were collected at 5-minute intervals for the first hour and at 20 -minute intervals during the second hour, and were placed immediately in tubes containing a dried heparin and sodium fluoride mixture. All analyses were completed the day of the test, using the Nelson-Somogyi method (30). Determinations were in duplicate and were read on a Model DU Beckman Spectrophotometer.

Data analysis. For each tolerance test, the observations obtained between 10 and 60 minutes of the experiment were fitted to the equation $\log _{\bullet} \mathrm{y}=\log _{\bullet} \mathrm{A}-\mathrm{kt}(\mathrm{y}=$ $\mathrm{Ae}^{-\mathrm{kt}}$ ) where $\mathrm{y}$ is the blood glucose concentration in

${ }^{3}$ We are indebted to Dr. W. R. Kirtley of Eli Lilly and Company for supplying us with HGF free Z.I.C. 40 units per $\mathrm{ml}$. 
TABLE I

Subject characteristics

\begin{tabular}{|c|c|c|c|c|c|}
\hline \multirow[b]{2}{*}{ Variable } & & \multicolumn{4}{|c|}{ Age group } \\
\hline & & Young & Middle & Old & Total \\
\hline $\mathbf{N}$ & & 12 & 11 & 12 & 35 \\
\hline Age (yrs.) & $\begin{array}{l}\text { Mean } \\
\text { Range }\end{array}$ & $\begin{array}{l}31.3 \\
23 \\
37\end{array}$ & $\begin{array}{l}49.1 \\
42 \\
58\end{array}$ & $\begin{array}{l}78.7 \\
65 \\
87\end{array}$ & $\begin{array}{l}53 \\
23 \\
87\end{array}$ \\
\hline Height (cm.) & $\begin{array}{l}\text { Mean } \\
\text { Fmoan } \\
\text { Range }\end{array}$ & $\begin{array}{r}175.3 \\
2.0 \\
165.7 \\
185.4\end{array}$ & $\begin{array}{r}174.4 \\
2.7 \\
165.1 \\
186.7\end{array}$ & $\begin{array}{r}162.6 \\
2.3 \\
143.5 \\
171.4\end{array}$ & $\begin{array}{r}170.8 \\
2.2 \\
143.5 \\
186.7\end{array}$ \\
\hline Weight $\left(K_{g}.\right)$ & $\begin{array}{l}\text { Mean } \\
\text { Fyoan } \\
\text { Range }\end{array}$ & $\begin{array}{r}71.0 \\
2.4 \\
57.3 \\
85.0\end{array}$ & $\begin{array}{r}64.6 \\
3.5 \\
52.0 \\
92.7\end{array}$ & $\begin{array}{r}66.8 \\
3.9 \\
45.1 \\
88.2\end{array}$ & $\begin{array}{r}67.5 \\
3.2 \\
45.1 \\
92.7\end{array}$ \\
\hline Surface area $\left(M .{ }^{2}\right)$ & $\begin{array}{l}\text { Mean } \\
\text { oxoan } \\
\text { Range }\end{array}$ & $\begin{array}{c}1.83 \\
.033 \\
1.67 \\
2.00\end{array}$ & $\begin{array}{c}1.77 \\
.047 \\
1.58 \\
2.08\end{array}$ & $\begin{array}{c}1.70 \\
.060 \\
1.39 \\
2.00\end{array}$ & $\begin{array}{l}1.77 \\
.040 \\
1.39 \\
2.08\end{array}$ \\
\hline Fasting blood glucose* & $\begin{array}{l}\text { Mean } \\
\text { Fmean } \\
\text { Range }\end{array}$ & $\begin{array}{c}68.0 \\
1.9 \\
60 \\
77\end{array}$ & $\begin{array}{c}78.5 \\
2.0 \\
64 \\
90\end{array}$ & $\begin{array}{c}85.0 \\
2.3 \\
70 \\
97\end{array}$ & $\begin{array}{c}77.1 \\
2.1 \\
60 \\
97\end{array}$ \\
\hline $\begin{array}{l}\text { Glucose administered } \\
(\mathrm{Gm} . / \mathrm{Kg} . \text { body } w t .)\end{array}$ & $\begin{array}{l}\text { Mean } \\
\text { Gyoan } \\
\text { Range }\end{array}$ & $\begin{array}{l}.356 \\
.012 \\
.294 \\
.436\end{array}$ & $\begin{array}{l}.397 \\
.018 \\
.270 \\
.454\end{array}$ & $\begin{array}{l}.389 \\
.024 \\
.283 \\
.554\end{array}$ & $\begin{array}{l}.381 \\
.020 \\
.270 \\
.554\end{array}$ \\
\hline
\end{tabular}

- Mean of control observations on glucose and glucose-insulin tests.

milligrams per $100 \mathrm{ml}$. and $t$ is time in minutes, following the injection of the glucose load. The method of least squares (31) was utilized for the computation of $A$ and $\mathbf{k}$ for each experiment. The value of $\mathbf{k}$ was taken as the index of tolerance for this study. The difference between the $k$ for the glucose $\left(k_{\theta}\right)$ and the glucoseinsulin test $\left(\mathrm{k}_{\mathrm{GI}}\right)$ is called $\Delta \mathrm{k}$ and served as the index of the response to insulin in each subject. Visual fits to plots of log of the glucose level against time were also made and compared with the least squares fitting.

Age changes in the data were evaluated by determining the regression of the derived measures on age and also by comparing mean values for three groups: young (12 subjects, age 20 to 39 years), middle (11 subjects, age 40 to 59 years), and old (12 subjects, age 60 to 90 years).

\section{RESULTS}

\section{Characterization of the subjects}

No significant $(P=>0.10)$ differences were found among the three age groups with respect to body weight, surface area or dose of glucose per $\mathrm{Kg}$. of body weight (Table I). A small, but statistically significant, increase in fasting venous blood sugar levels with age was observed in this sample.

\section{Reliability of methods}

The standard deviation of repeated glucose determinations on a single filtrate was $\pm 1.1 \mathrm{mg}$. per cent $(N=58)$. Comparing two filtrates, prepared from the same blood sample, the standard deviation was $2.1 \mathrm{mg}$. per cent $(\mathrm{N}=53)$.

There was no systematic difference between fasting blood sugar levels determined on the same individual on different days. The standard error of estimate between measurements made on the first and second days was $\pm 6.5 \mathrm{mg}$. per 100 ml. ${ }^{4}$

In the 8 subjects ( 4 old and 4 middle-aged) who had duplicate glucose tolerance and glucoseinsulin tolerance tests, no significant differences occurred between the results of the first and second tests, with respect to $k_{G}$ or $k_{G I}$. The dupli-

4 Mean values are reported with standard errors of the mean. 


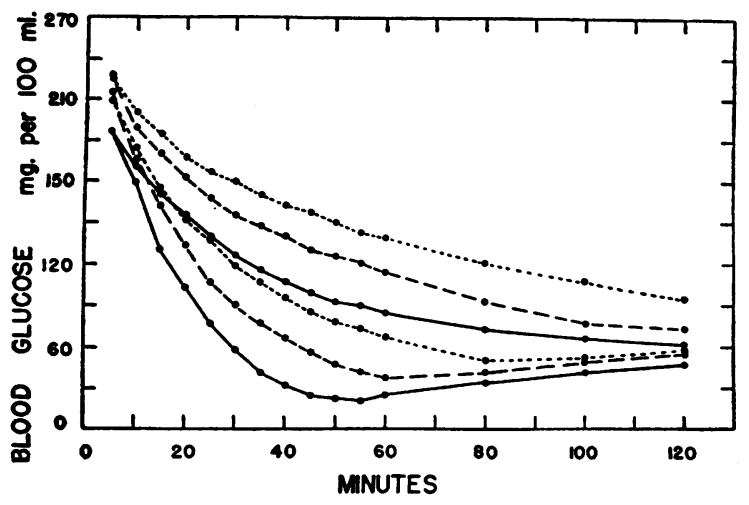

Fig. 1. Linear Plots of Average Blood Sugar ValUES (MG. PER 100 ML.) at EACH Tmae Interval (MTr.) Following the Intravenous Administration of 25 GM. Glucose for Each of Three Age Groups

Glucose tolerance (GTT) open circles; glucose plus 5 units insulin per sq. M. surface area (GITT) closed circles; old subjects ( 65 to 87 years old) dotted lines; middle-aged subjects ( 42 to 58 years old) dashed lines, and young subjects ( 23 to 37 years old) solid lines.

cate tests were not performed in any specific order; the lapse of time between tests varied from one week to three months. In contrast to results reported by Hlad, Elrick, and Witten (32) values for $k_{G}$ or $k_{G I}$ were repeatable and characteristic for the individual.

\section{General description of results}

Average values of blood sugar concentration at each time interval, following the administration of glucose, are plotted for each of the three age

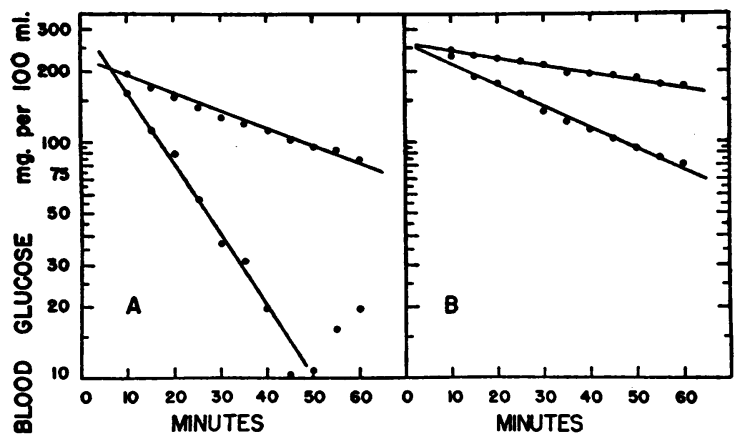

Fig. 2. Estmation of $\mathbf{K}_{0}$ aNd $\mathrm{K}_{\mathrm{gi}}$ IN Indvidual EXPERTMENTS

Log glucose concentration in blood (mg. per $100 \mathrm{ml}$ ) plotted against time (min.). A. Young subject (26-yearold). B. Old subject (86-year-old). Upper lines (open circles) represent data from GTT; lower lines (solid circles) represent data from GITT. groups in Figure 1. The rate of fall in blood glucose level was greater for the young than for the old subjects under both experimental conditions. When tests of significance of age differences were applied to specific time points along the glucose or glucose-insulin tolerance curves, true differences $(P<0.001)$ were found between young and old subjects at 15,30 , and 60 minutes after injection of the glucose. Differences over shorter age spans, i.e., between young and middle, and middle and old subjects, were usually significant at $P<0.01$ or $P<0.05$.

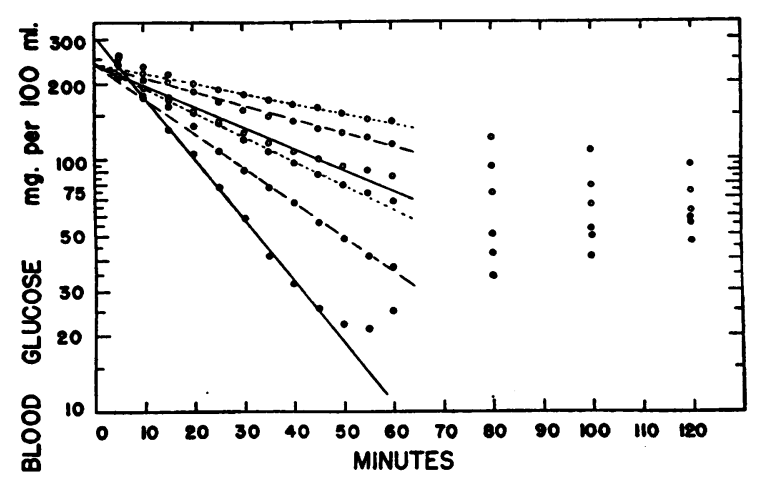

Fig. 3. Age Diffrerence in $k_{G}$ ANd $K_{g I}$

Plots of log glucose concentration in the blood (mg. per $100 \mathrm{ml}$.) against time ( $\mathrm{min}$.) following intravenous administration of $25 \mathrm{Gm}$. glucose. Glucose tolerance (GTT) open circles; glucose plus 5 units insulin per M.' surface area (GITT) solid circles; old subjects (65 to 87 years old) dotted lines; middle-aged subjects (42 to 58 years old) dashed lines, and young subjects ( 23 to 37 years old) solid lines. (Lines are fitted to points for 10 to $60 \mathrm{~min}$. inclusive.)

\section{Age differences in rate of disappearance of glu- cose from the blood}

When the log glucose concentration was plotted against time, a linear relationship was obtained for the points between ten and 50 to 60 minutes. Sample plots for a young (26-year-old) and an old (86-year-old) subject are shown in Figure $2 \mathrm{~A}$ and $2 \mathrm{~B}$. Figure 3 shows the $\log$ of the mean glucose values for the three groups of 8 subjects, plotted against time after glucose administration. Deviations from linearity are apparent in all curves beyond 50 or 60 minutes. Therefore, the expression $\log _{\mathrm{e}} \mathrm{y}=\log _{\mathrm{e}} \mathrm{A}-\mathrm{kt}$ fails to describe the total process, but may be used to derive an index of the rate of disappearance of glucose from the 


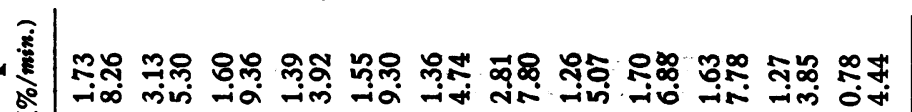
:요 90.

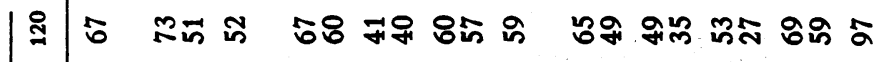

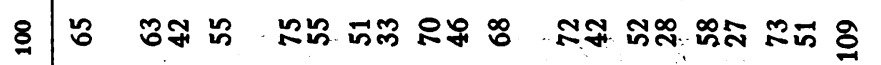

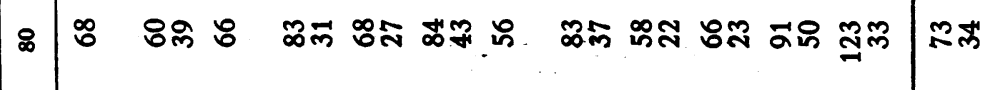

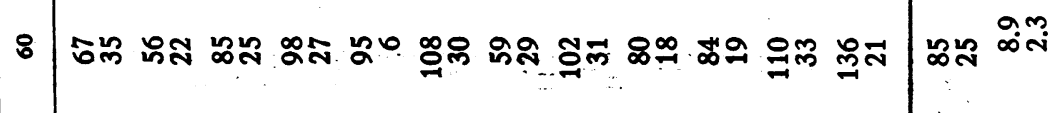

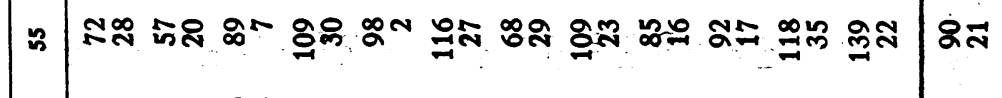

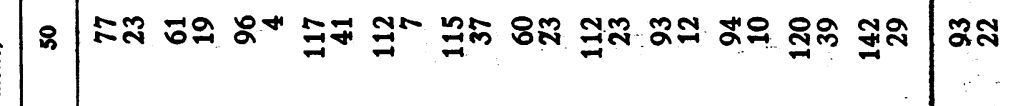

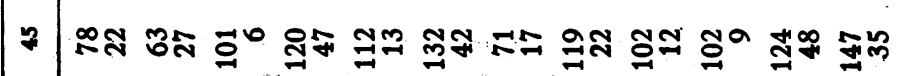
ละก ธี่

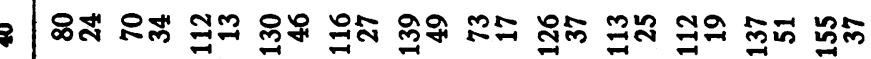
క్య

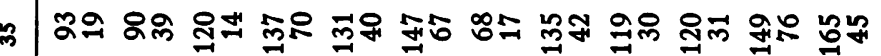
$\stackrel{7}{7}$

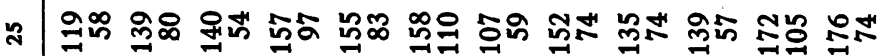

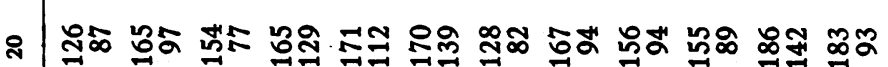
$\sin$

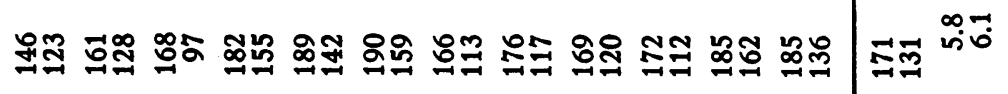

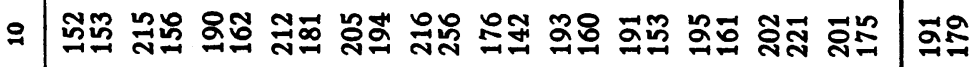

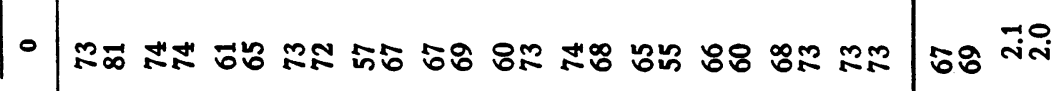
责 商

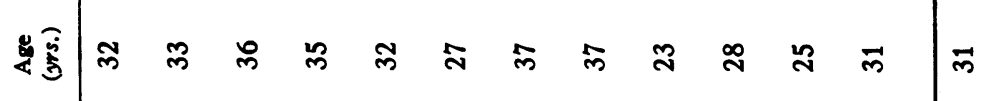

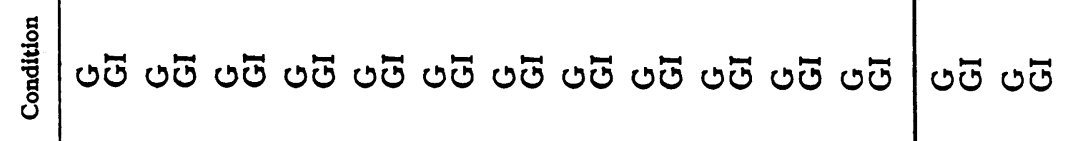

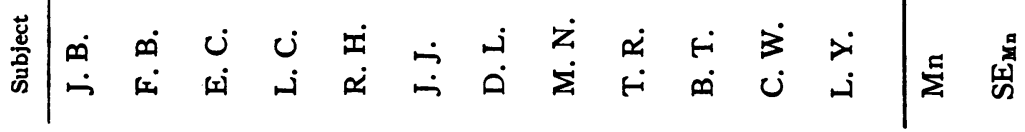




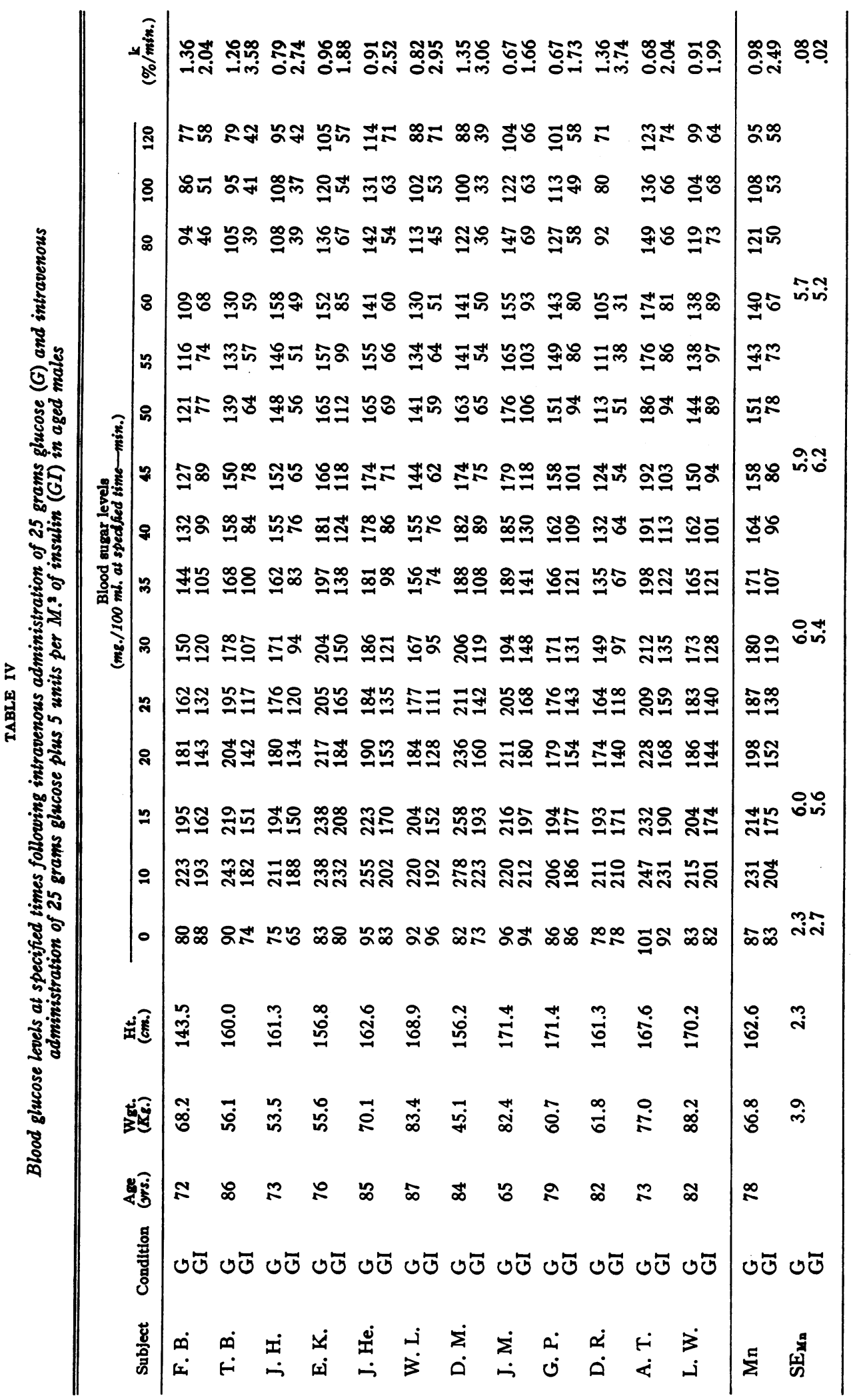


TABLE V

Rate of disappearance of glucose from the blood with ( $\left.k_{G I}\right)$ and without insulin $\left(k_{G}\right)$

( $k$ expressed as per cent per minute)

\begin{tabular}{|c|c|c|c|c|c|c|c|c|c|c|}
\hline \multirow[b]{3}{*}{ Age group } & \multirow[b]{3}{*}{$\mathbf{N}$} & \multicolumn{6}{|c|}{ Venous blood } & \multirow{2}{*}{\multicolumn{3}{|c|}{ 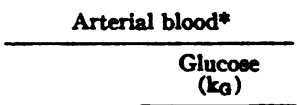 }} \\
\hline & & \multicolumn{2}{|c|}{$\underset{\left(k_{G}\right)}{\text { Glucose }}$} & \multicolumn{2}{|c|}{$\begin{array}{c}\text { Glucose-insulin } \\
\left(k_{a I}\right)\end{array}$} & \multicolumn{2}{|c|}{$\begin{array}{l}\text { Diff. } \\
(\Delta \mathbf{k})\end{array}$} & & & \\
\hline & & Mn. & $\overline{\sigma_{\mathrm{Mn} .}}$ & Mn. & $\overline{\sigma_{\text {Mn. }}}$ & Mn. & $\overline{\sigma_{\mathbf{Y n} .}}$ & $\mathbf{N}$ & $\mathbf{M n}$. & $\sigma_{\text {ma. }}$ \\
\hline $\begin{array}{l}\text { Young } \\
\text { Middle } \\
\text { Old }\end{array}$ & $\begin{array}{l}12 \\
11 \\
12\end{array}$ & $\begin{array}{l}1.68 \\
1.44 \\
0.98\end{array}$ & $\begin{array}{l}.19 \\
.21 \\
.08\end{array}$ & $\begin{array}{l}6.39 \\
3.61 \\
2.49\end{array}$ & $\begin{array}{l}.60 \\
.25 \\
.02\end{array}$ & $\begin{array}{l}4.12 \\
2.17 \\
1.52\end{array}$ & $\begin{array}{l}.59 \\
.26 \\
.17\end{array}$ & $\begin{array}{l}13 \\
13 \\
38\end{array}$ & $\begin{array}{l}1.94 \\
1.61 \\
1.28\end{array}$ & $\begin{array}{l}.20 \\
.09 \\
.06\end{array}$ \\
\hline Total & 35 & 1.37 & .11 & 4.15 & .11 & 2.62 & .09 & 64 & 1.48 & .07 \\
\hline
\end{tabular}

* Data from Smith and Shock (19) recalculated.

blood during the first 50 to 60 minutes of the experiment. Examination of Figure 3 shows that: (a) the early rate of disappearance of excess of glucose from the blood was more rapid in the young than the old, (b) the rate of disappearance was increased in all age groups by the simultaneous administration of insulin, and (c) the influence of insulin was greater in the young than the old subjects.

Computations by the method of least squares of the slope for each individual test provided data for estimates of the variability of $\mathbf{k}$ within each age group. Tables II, III, and IV present the values of $k$ for both the GTT and the GITT with increasing age. Average values of $\mathbf{k}$, expressed as per cent per minute, for the young and old, respectively, were as follows: $k_{G}, 1.68$ and 0.98 ; $k_{G I}, 6.39$ and 2.49 , and $\Delta k\left(k_{G I}-k_{G}\right), 4.12$ and 1.52. Values of $P$ were less than 0.01 for these age differences. Regressions of $\mathbf{k}$ on age were significant at the 0.01 level for $k_{G}$ and at less than 0.001 for $k_{\mathrm{GI}}$ and $\Delta \mathrm{k}$. The effect of insulin in the average adult male was to increase the rate of fall in blood glucose level from 1.37 per cent per minute to 4.15 per cent per minute.

\section{DISCUSSION}

\section{Subject selection-Activity and diet}

Since age differences in glucose tolerance are relatively small, it is necessary to give careful consideration to the selection of subjects. In order to minimize the effects of prior diet, which has been shown to have an influence on the glucose tolerance (33-36), only subjects who had been on a standard hospital diet for at least one week were tested in the present series.
Since reduced activity has been shown to reduce glucose tolerance $(36,37)$, only ambulatory patients were studied. The young subjects were also patients drawn from an ambulatory inhospital population. Thus, the level of activity was probably more uniform between the different age groups than would have been the case had staff members been used for the younger age groups.

\section{Dose of glucose and insulin}

Although different amounts of glucose have been used by previous investigators, recent studies have shown that adjustment of the dose of glucose to body size is unnecessary $(18,28,38)$. Consequently, a standard dose of $25 \mathrm{Gm}$. of glucose was administered at a uniform rate $(18,38)$ to all subjects in the present study. The glucose load varied from $0.57 \mathrm{Gm}$. per $\mathrm{Kg}$. to $0.27 \mathrm{Gm}$. per $\mathrm{Kg}$. in different subjects, but there were no systematic differences between age groups (Table I). The dose of insulin was set at 5 units per M.2, which is approximately 0.1 unit per $\mathrm{Kg}$. body weight. Experimental studies (22-24, 27, 39-41) indicate that insulin gives a maximum effect on rate response at dose levels of 0.05 unit per $\mathrm{Kg}$. and up to 0.3 unit per $\mathrm{Kg}$. The effect of differences in endogenous insulin production would be obliterated at this dose range of injected insulin.

\section{Comparison of venous and arterial blood samples}

Nelson's modification of the Somogyi method (30) was used for sugar determination in this study in order to minimize the effects of nonfermentable reducing substances $(42,43)$. The use of venous blood samples in conjunction with an 
indwelling needle has the advantages of good patient acceptability and a minimum of patient trauma (44-46). Although the differences between arterial and venous blood glucose levels are small under fasting conditions (arterial bloods average $9 \mathrm{mg}$. per $100 \mathrm{ml}$. higher than venous), there is a wide range of individual variation ( 1 to $17 \mathrm{mg}$. per $100 \mathrm{ml}$. in normal subjects) and the difference increases markedly (average 30 to 43 mg. per $100 \mathrm{ml}$.) following the administration of glucose $(43,47)$. Since Blotner $(37)$ has found that glucose tolerance determined on venous blood samples was influenced less by physical activity in both children and adults than were estimates derived from capillary blood samples, it follows that the use of venous blood might be a more adequate test of age differences in glucose tolerance.

Since previous studies of glucose tolerance from this laboratory were based on arterial blood samples (19), the data were fitted to the tolerance equation. A total of 64 subjects, divided into three age groups, were tested under conditions closely approximating the present study, except that blood samples were drawn from the femoral artery (19). Insulin was not given. Table V gives the $\mathrm{k}$ values based on arterial blood samples. $^{5}$ As was true for venous blood samples, there was a significant decrement in $\mathrm{k}_{\mathrm{G}}$ with increasing age. However, the trend toward increasing fasting blood sugar levels with age, found in the present study on venous blood and in the report on capillary blood by Schneeberg and Finestone (20), was not apparent in arterial blood.

\section{The tolerance equation}

One simple expression which can serve to express the rate of disappearance of glucose from

\footnotetext{
${ }^{5}$ Arterial $k$ values were based on a visual fit. A comparison between the derivations of $\mathbf{k}$ by least squares and graphic estimates, made from a visually fitted line using the venous data, gave mean values of $137\left(\mathrm{k} \times 10^{4}\right)$ for both methods for the GTT $(r=0.96)$. For the GITT, the mean values of $k$ by the least squares' method was 415 as compared to 439 by the visual method ( $r=0.89$ ). Age did not influence the correlation between methods. Thus, a visual fit to the data yields substantially the same results as analysis by least squares. However, the latter permits a quantitative statement of the "goodness of fit" of the equation. This is not possible when the visual method above is used. Age did not influence the goodness of fit.
}

the blood, as a single number, is the equation $\log _{e} y=\log _{e} A-k t \quad(48-51)$. If one assumes that no distinction is made between the glucose added to the blood from an external source and the glucose added by the liver or other cells of the body, the estimates of the slope of the curve must be made on the total glucose content at successive time intervals. This assumption may be applied safely only to the early parts of the curve, since it is obvious that alterations in the glucose concentration will be introduced by other processes in the body which tend to add glucose to the circulation, particularly when blood sugar levels fall to low values, as in the case when insulin is administered. Greville (50) as well as Hlad, Elrick, and Witten (32) found that subtraction of a calculated asymptotic value of blood sugar level resulted in a somewhat better fit to glucose tolerance data beyond 90 minutes. In this study where curves were limited to the first 60 minutes, the fit was very good; the introduction of an asymptote had only a small insignificant effect on goodness of fit. Furthermore, the use of an asymptote gave rise to difficulties in comparing the GTT and the GITT, since subtraction of a calculated asymptote for the glucose-insulin curves often resulted in values less than zero. Although the value of $\mathbf{k}$ is related to the level of the asymptote, both parameters are determined by the same set of experimental points.

In agreement with other studies (49-51), the blood glucose level at 5 minutes, following the injection, was found to be higher than predicted from the exponential curve, suggesting an interaction with the early extra-cellular mixing phase. By 10 minutes after the glucose injection, the mixing phase is indistinguishable from the body of the curve. Conard, Franckson, Bastenie, Kestens, and Kovacs (52) injected glucose and thiocyanate simultaneously and found a thiocyanate space of $14.31 \mathrm{~L}$. and a glucose space of $14.01 \mathrm{~L}$. In our experiments, the average glucose space was 14.1 L. or 22 per cent of the body weight. This value is only slightly lower than the glucose space (23.3 per cent of body weight) reported by Hlad, Elrick, and Witten (32) on the basis of continuous infusions of glucose. Since there are no significant changes with age in the thiocyanate space (53), it appears that the values of $k$ are determined by the distribution of glucose in 
the intra-cellular fluids and metabolic pathways, and are influenced very little by extra-cellular mixing and not in a manner which is age biased.

\section{Age differences}

Although there is an overall reduction in the rate of removal of glucose from the blood and a reduced response to insulin with increasing age, it cannot be assumed that this reduction is necessarily associated with altered cellular metabolism. A similar overall effect could result from a reduction in the number of metabolizing units. Other studies from this laboratory have indicated a gradual loss of metabolizing tissue with increasing age (54). This conclusion is based on the observed decrease in intra-cellular water (antipyrine space minus thiocyanate space) with age. The intra-cellular space, calculated in this fashion, averages $10.5 \mathrm{~L}$. in young and $8.6 \mathrm{~L}$. in aged subjects; a reduction of 18 per cent. Over the same age span, $k$ shows a reduction of 42 per cent for the glucose tolerance data and 61 per cent for the glucose-insulin tests. Although the data do not represent observations made on the same subjects, and the dimensions are incongruous, it seems difficult to account for all of the changes observed on the basis of a loss of functioning protoplasm alone.

It is conceivable that the age differences in the rate of removal of glucose from the blood might be due to differences in blood flow and delivery of glucose to the tissues. Clearly, a reduction in the total amount of blood delivered, per unit of time, would influence $\mathbf{k}$ if all the glucose were removed in a single passage through a vascular bed. However this is not the case. If there were a substantial reduction in blood flow to tissues in the older subject, an increase in the A-V difference should appear. Since we do not have simultaneous arterial and venous glucose levels on the same subjects, no final decision can be reached on this question, but it does not seem likely that differences in blood flow can account for the age differences observed.

It is recognized that the concentration of glucose in the blood at any given time represents an equilibrium between the rate of removal and the rate of release of glucose from the liver. The differential effect of insulin in the three age groups makes it improbable that the results obtained can be ascribed to differences in the rate of release of glucose from the liver in the old and young subjects. Recent studies indicate that the early effect of insulin action is that of increasing peripheral uptake and metabolism of glucose. The liver response is minimal and delayed (55).

Inactivation of insulin by a plasma constituent may be a factor in some phases of diabetes, particularly in regard to the mechanism of clinical insulin resistance. Welsh, Henley, Williams, and Cox (56) studied the plasma binding of insulin $\mathrm{I}^{131}$ in 118 subjects, 43 of which were non-diabetic ranging from 14 years to 90 years of age. Analyzing their data with reservation for the inclusion of patients with other active disease in their group of non-diabetic controls, no trend is discernible between the age of the subject and the potential insulin inactivation by plasma binding.

Although proof cannot be offered, it seems reasonable to assume that at least part of the age differences can be ascribed to alterations in the metabolic effectiveness and response of the functioning cells in the aged male.

\section{SUMMARY}

Intravenous glucose tolerance and glucoseinsulin tolerance tests were performed on 35 normal male subjects under standardized conditions using venous blood samples. The subjects ranged in age from 23 to 86 years. Blood samples drawn at 5-minute intervals, between 5 and 60 minutes after administration of $25 \mathrm{Gm}$. glucose, were analyzed for glucose by the Nelson method. The rate of fall of the blood sugar level between 10 and 60 minutes was determined by fitting the experimental points to the equation $\log _{\mathrm{e}} \mathrm{y}=\log _{\mathrm{e}} \mathrm{A}-$ kt. A significant decrease in $\mathrm{k}$ with age was observed in both the glucose and the glucose-insulin tolerance curves. The administration of insulin had a greater effect on the rate of disappearance of glucose from the blood in the young than the old subjects. It is proposed that the age difference may result from both a reduction in the amount of functioning protoplasm and an alteration in intra-cellular glucose metabolism.

\section{ACKNOWLEDGMENTS}

We wish to express our appreciation to Dr. W. L. Fleck, Veterans Hospital, Fort Howard, for making some of the patients available for these studies; Dr. 
Milton Landowne for his thoughtful criticism; Dr. Max Halperin for statistical consultation; Miss Janet Lewis and Mr. William Martin for technical assistance, and to Mrs. Elizabeth Benser for computational aid.

\section{REFERENCES}

1. Spence, J. C., Some observations on sugar tolerance, with special reference to variations found at different ages. Quart. J. Med., 1921, 14, 314.

2. Löffler, W., Das Verhalten des Blutzuckers in verschiedenen Altersstufen nach Einnahme von Glucose per os. Biochem. Ztschr., 1922, 127, 316.

3. Punschel, A., Der Blutzucker im höheren Lebensalter under besonderer Berücksichtigung der alimentären Hyperglykämie. Ztschr. klin. Med., 1923, 96, 253.

4. Hale-White, R., and Payne, W. W., The dextrose tolerance curve in health. Quart. J. Med., 1926, 19, 393.

5. Porter, E., and Langley, G. J., Studies in blood-sugar. Lancet, 1926, 2, 947.

6. Marshall, F. W., The sugar-content of the blood in elderly people. Quart. J. Med., 1931, 24, 257.

7. Rømcke, O., Der Blutzucker im älteren Alter, insbesondere bei hypertonischen Zuständen. Acta med. Scandinav., 1931, 76, Suppl. 39.

8. John, H. J., Glucose tolerance studies in children and in adolescents. Endocrinology, 1934, 18, 75.

9. Sharma, G. L., Observations on the sugar tolerance of healthy aged Indians. J. Indian M. A., 1938, 7, 641.

10. Kohl, H., and Dahmann, H., Blutzuckerbelastungen in verschiedenen Lebensaltern. Ztschr. Altersforsch., 1940, 2, 310.

11. Klotzbücher, E., Die Alternsabhängigkeit des Kohlehydratstoffwechsels. Ergebnisse von Insulin und Kohlehydratdoppelbelastungen in den verschiedenen Altersstufen. Ztschr. Altersforsch., 1944, 4, 354.

12. Aaltonen, K. E., Klinische Beobachtungen an Greisen, die das achtzigste Lebensjahr vollendet haben. Acta med. Scandinav., 1939, 99, 356.

13. Hofstatter, L., Sonnenberg, A., and Kountz, W. B., The glucose tolerance in elderly patients. Biol. Symposia, 1945, 11, 87.

14. Deren, M. D., Dextrose tolerance in the aged. J. Lab. \& Clin. Med., 1937, 22, 1138.

15. Simon, W., and Garvey, J. T., Glucose tolerance in chronic schizophrenia and senile states. Arch. Neurol. \& Psychiat., 1951, 65, 717.

16. Chesrow, E. J., and Bleyer, J. M., The glucose tolerance test on the aged. Geriatrics, 1954, 9, 276.

17. Horvath, S. M., Wisotsky, R., and Corwin, W., The oral glucose tolerance test in old men. J. Gerontol., 1947, 2, 25.

18. Tunbridge, R. E., and Allibone, E. C., The intravenous dextrose tolerance test. Quart. J. Med. 1940, 9, 11.
19. Smith, L. E., and Shock, N. W., Intravenous glucose tolerance tests in aged males. J. Gerontol., 1949, 4, 27.

20. Schneeberg, N. G., and Finestone, I., The effect of age on the intravenous glucose tolerance test. J. Gerontol., 1952, 7, 54.

21. Engel, F. L., and Scott, J. L., The insulin-glucose tolerance test. A modified procedure for the detection of hypoglycemia unresponsiveness in pituitary and adrenal insufficiency. J. Clin. Invest., 1950, 29, 151.

22. Himsworth, H. P., Diabetes mellitus. Its differentiation into insulin-sensitive and insulin-insensitive types. Lancet, 1936, 1, 127.

23. Himsworth, H. P., and Kerr, R. B., Age and insulin sensitivity. Clin. Sc., 1939, 4, 153.

24. Himsworth, H. $P_{\text {., }}$ and Kerr, R. B., Insulin-sensitive and insulin-insensitive types of diabetes mellitus. Clin. Sc., 1942, 4, 119.

25. Cleempoel, H., Conard, V., and Bastenie, P. A., Carcinoma of the islets of Langerhans. A test for hyperinsulinism. Lancet, 1955, 2, 801.

26. Waller, J. J., Stribling, S. H., and Spurr, C. L., The effect of various disease states on the intravenous glucose tolerance test and the glucose insulin tolerance test. Clin. Research Proc., 1955, 3, 15.

27. Fraser, R., Albright, F., and Smith, P. H., Carbohydrate metabolism. The value of the glucose tolerance test, the insulin tolerance test, and the glucose-insulin tolerance test in the diagnosis of endocrinologic disorders of glucose metabolism. J. Clin. Endocrinol., 1941, 1, 297.

28. Lozner, E. L., Winkler, A. W., Taylor, F. H. L., and Peters, J. P., The intravenous glucose tolerance test. J. Clin. Invest., 1941, 20, 507.

29. Loughlin, W. C., Mosenthal, H. O., and Halpern, R., Effect of tourniquets on venous blood sugar values. J. Lab. \& Clin. Med., 1943, 28, 1165.

30. Nelson, N., A photometric adaptation of the Somogyi method for the determination of glucose. J. Biol. Chem., 1944, 153, 375.

31. Peters, C. C., and Van Voorhis, W. R., Statistical Procedures and Their Mathematical Bases. New York, McGraw-Hill Company, 1940.

32. Hlad, C. J., Jr., Elrick, H., and Witten, T. A., Studies on the kinetics of glucose utilization. J. Clin. Invest., 1956, 35, 1139.

33. Sweeney, J. S., Dietary factors that influence the dextrose tolerance test. Arch. Int. Med., 1927, 40, 818.

34. Himsworth, H. P., Dietetic factors influencing the glucose tolerance and the activity of insulin. J. Physiol., 1934, 81, 29.

35. Conn, J. W., Interpretation of the glucose tolerance test. The necessity of a standard preparatory diet. Am. J. M. Sc., 1940, 199, 555.

36. Ingle, D. J., Some studies on factors which influence tolerance for carbohydrate. Proc. Am. Diabetes A., 1948, 8, 113. 
37. Blotner, H., Effect of prolonged physical inactivity on tolerance of sugar. Arch. Int. Med., 1945, 75, 39.

38. Amatuzio, D. S., Stutzman, F. L., Vanderbilt, M. J., and Nesbitt, S., Interpretation of the rapid intravenous glucose tolerance test in normal individuals and in mild diabetes mellitus. J. Clin. Invest., 1953, 32, 428.

39. McKean, R. M., Myers, G. B., and Von der Heide, E. C., Blood glucose clearance. Its determination by a microinterval method. I. Studies in normal and diabetic persons. Am. J. M. Sc., 1935, 189, 702.

40. Volk, B. W., and Lazarus, S. S., The effect of varying insulin dosages on the rate of decline of the blood sugar in the modified ghucose insulin tolerance test. J. Lab. \& Clin. Med, 1953, 41, 684.

41. Somogyi, M., Studies of arteriovenous differences in blood sugar. III. Effect of insulin administered intravenously in the postabsorptive state. J. Biol. Chem., 1949, 179, 217.

42. Mosenthal, H. O., and Barry, E., Advantages of true venous blood sugar values for glucose tolerance tests. New York State J. Med., 1946, 46, 2513.

43. Mosenthal, H. O., and Barry, E., Evaluation of blood sugar tests: significance of the non-glucose reducing substances and the arterio-venous blood sugar difference. Am. J. Digest. Dis., 1946, 13, 160.

44. Hinkle, L. E., Jr., and Wolf, S., The effects of stressful life situations on the concentration of blood glucose in diabetic and nondiabetic humans. Diabetes, 1952, 1, 383.

45. Mirsky, I. A., Emotional hyperglycemia. Proc. Central Soc. Clin. Research, 1946, 19, 74.

46. Mosenthal, H. O., and Barry, E., Criteria for and interpretation of normal glucose tolerance tests. Ann. Int. Med., 1950, 33, 1175.
47. Langner, P. H., Jr., and Fies, H. L., Blood sugar values of blood obtained simultaneously from the radial artery, antecubital vein and the finger. Am. J. Clin. Path., 1942, 12, 559.

48. Pijoan, M., and Gibson, J. G., II, The rate of disappearance of intravenously administered dextrose in the human subject. Am. J. Physiol., 1938, 121, 534.

49. Hamilton, B., and Stein, A. F., The measurement of intravenous blood sugar curves. J. Lab. \& Clin. Med., 1942, 27, 491.

50. Greville, G. D., The intravenous glucose tolerance equation. Biochem. J., 1943, 37, 17.

51. Jokipii, S. G., and Turpeinen, O., Kinetics of elimination of glucose from the blood during and after a continuous intravenous injection. $\mathrm{J}$. Clin. Invest., 1954, 33, 452.

52. Conard, V., Franckson, J. R. M., Bastenie, P. A., Kestens, J., and Kovacs, L., Etude critique du triangle d'hyperglycémie intraveineux chez l'homme normal et détermination d'un "coefficient d'assimilation glucidique." Arch. Int. Pharmacodyn., 1953, 93, 277.

53. Shock, N. W., Watkin, D. M., and Yiengst, M. J., Metabolic aspects of aging in Old Age in the Modern World. Report of 3rd Cong. Int. Assoc. Geront., London, 1954, Edinburgh. E. \& S. Livingstone, Ltd., 1955, p. 127.

54. Shock N. W., Metabolism and age. J. Chronic Dis., $1955,2,687$.

55. Renold, A. E., Hastings, A. B., Nesbett, F. B., and Ashmore, J., Studies on carbohydrate metabolism in rat liver slices. IV. Biochemical sequence of events after insulin administration. J. Biol. Chem., 1955, 213, 135.

56. Welsh, G. W., III, Henley, E. D., Williams, R. H., and Cox, R. W., Insulin I-131 metabolism in man. Am. J. Med., 1956, 21, 324. 